\title{
Purification and Characterization of a Novel $p, p$ '-DDT Dehalogenase from Aeromonas sp. strain MY1
}

\author{
*1MURTALA, Y; ${ }^{1,2}$ NWANGUMA, BC $;{ }^{2}$ EZEANYIKA, LUS \\ ${ }^{*}$ Department of Biochemistry, Faculty of Basic Medical Sciences, Bayero University, Kano, Nigeria \\ ${ }^{2}$ Department of Biochemistry, Faculty of Biological Sciences, University of Nigeria, Nsukka, Nigeria \\ *Corresponding Author Email: myau.bch@buk.edu.ng
}

\begin{abstract}
Although dichlorodiphenyltrichloroethane (DDT) occupies a prominent position for its recalcitrance in the environment which led to its ban by the Stockholm Convention. This pesticide is still unregulated used in low and middle-income countries, which contributes to the global burden of this hazardous contaminant. In the recent time, biological approach has been proven to be effective and environmentally safer for the decontamination of the residual DDT. In this research, we reported a gel-purified $p, p^{\prime}$-DDT dehalogenase from Aeromonas sp. strain MY1, revealing a single band with a molecular weight of approximately $37 \mathrm{kDa}$. The dehalogenase was unique for its capability to release chloride ions from $p, p^{\prime}$-DDT substrate with optimum dechlorination activity at $\mathrm{pH} 8.0$ and $35^{\circ} \mathrm{C}$. The enzyme followed Michaelis-Menten's kinetics and measurement of its initial velocities with various $p, p$ '-DDT concentrations showed a $\mathrm{Km}$ of $27.05 \mu \mathrm{mol} \mathrm{L}{ }^{-1}$ and $\mathrm{Vmax}$ of $476.19 \mu \mathrm{mol} \mathrm{L}^{-1} \mathrm{~min}^{-1}$. However, the enzyme lost its dechlorination activity in the presence of $\mathrm{Ag}^{2+}$ and $\mathrm{Hg}^{2+}$ This dehalogenase could pave a way for the effective decontamination of $p, p$ 'DDT contaminated environment, suggesting its potentials for $p, p$ '-DDT bio-cleansing applications.
\end{abstract}

\section{DOI: https://dx.doi.org/10.4314/jasem.v24i12.15}

Copyright: Copyright (C) 2020 Murtala et al. This is an open access article distributed under the Creative Commons Attribution License (CCL), which permits unrestricted use, distribution, and reproduction in any medium, provided the original work is properly cited.

Dates: Received: 10 September 2020; Revised: 30 November 2020; Accepted: 19 December 2020

Keywords: Aeromonas sp., p,p'-DDT, dehalogenase, bioremediation, halogenated aromatic contaminants

The environmental widespread and realization of the devastating ecological and health impacts of halogenated aromatic compounds, particularly organochlorine pesticides in which 1-chloro-4-[2,2,2,trichloro-1-(4chlorophenyl)ethyl]benzene (DDT) occupies a prominent position for its recalcitrance, led to the ban of this compound and other Persistent Organic Pollutants (POPs) by the Stockholm Convention in 2001. However, DDT is still unregulated used for disease vector control in many parts of low and middle-income Africa, the Pacific, and Asia (van den Berg et al., 2017; Abdul Kader, 2019). The inherent environmental persistence demonstrated by DDT and its metabolites made them traceable in ambient air, domestic water supply, and other food varieties (Bussolaro et al., 2012; Anand, 2019; Wu et al., 2019; Mendes et al., 2019; Sheldon et al., 2019 Thompson et al., 2019). Some reports on environmental and human toxicity showed that DDT intake is still occurring even in countries that fully respect the Stockholm Convention (Sudharshan et al., 2012). In many foods, the levels of DDT in many cases exceeded the U.S. Environmental Protection Agency permitted daily threshold (Sheldon et al., 2019). Ogbeide et al. (2015) detected DDT in domestic water samples from Nigeria. DDT has been known to be associated with several human health implications, ranging from endocrine disruption, muscular dysfunction, and probable carcinogenicity (Mnif et al., 2011; Hadara et al., 2016; Piazza and Urbanetz, 2019; Truong et al., 2019; Cohn et al., 2019). Thus, still, there is an urgent need to remove the residual DDT from the environment to ensure the safety of the ecosystem. DDT and its metabolites can be removed from the polluted sites by both physical and biological decontamination approaches. However, due to the relative chemical stability of DDT, the physical approach remains ineffective (Foght et al., 2001). Thus, the biological approach has been used and proven to be effective, safer, and environmentally friendly in the decontamination of the residual DDT (Fang et al., 2010; Mwangi et al., 2010; Abdul Hamid et al., 2011). In recent times, microbial dehalogenases that cleavage carbon-halogen bonds have been captivating the interest of the scientific community for their potentials in biotechnological applications in the decontamination of halogenated organic pollutants (Liang et al., 2019). Most of the microbial dehalogenases that have been reported are known to catalyze the cleavage of halogen atoms from the halogenated aliphatic compounds (Magnuson et al., 2000; Abdul Hamid et al., 2011; Jugder et al., 2016; Jugder et al., 2017). However, only a few dehalogenases were reported to dehalogenate the 
halogenated aromatic contaminants. This research focused on the partial purification and characterization of $p, p$ '-DDT-dehalogenase from Aeromonas sp. strain MY1 isolated from pesticide-contaminated sites.

\section{MATERIALS AND METHODS}

Aeromonas sp. strain MY1: The Aeromonas sp. strain MY1 was the source of the enzyme ( $p, p$ '-DDT dehalogenase). The organism was isolated from pesticide-contaminated soil located at Phase I, Kadawa Irrigation Site, Hadejia-Jama'are River Basin, Kano State, Nigeria. The isolate was previously identified as Aeromonas sp. strain MY1 by a research team at the Bio-cleansing Annex, Center for Biotechnology Research, Bayero University, Kano, Nigeria. The strain was found to grow in the $p, p$ '-DDT enrichment medium (Murtala et al., 2020), and its 16S ribosomal RNA partial gene sequence can be found in the public databases of the National Center for Biotechnology Information (NCBI) under the universal accession number MN530936.

Enzyme purification: The enzyme extraction and purification protocols were carried out by modification of Motosugi et al. (1982) enzyme purification procedure. All protocols were carried out at $4{ }^{\circ} \mathrm{C}$ unless otherwise specified.

Cells harvest: An LB broth containing $20 \mathrm{~g}$ BactoTryptone, $10 \mathrm{~g}$ yeast extracts, and $20 \mathrm{~g} \mathrm{NaCl}$ in $2 \mathrm{~L}$ of distilled and sterilized water was prepared as a large-scale medium to rapidly grow the strain MY1. For the growth of the isolate, a large and sterilized (4 L) flask was used for inoculation. The strain MY1 was used to inoculate $2 \mathrm{~L}$ LB medium and incubated overnight at $37^{\circ} \mathrm{C}$ and $200 \mathrm{rpm}$ for $24 \mathrm{~h}$. Before the inoculation, $0.1 \mathrm{mg} \mathrm{mL}^{-1}$ of $p$, $p$ '-DDT was added into the growth medium as an inducer of dehalogenases. After getting sufficient growth in $24 \mathrm{~h}$, the bulk medium was centrifuged using $1200 \mathrm{R} \mathrm{Nuve}^{\mathrm{TM}}$ (Turkey) refrigerated centrifuge at $4{ }^{\circ} \mathrm{C}$ and 10,000 rpm for $15 \mathrm{~min}$. The pellet obtained was re-suspended in $50 \mathrm{~mL}$ of $50 \mathrm{mM}$ potassium phosphate buffer $(\mathrm{pH}$ 7.5 ) and re-centrifuged at $10,000 \mathrm{rpm}$ for $10 \mathrm{~min}$. The supernatant was discarded and the pellet was again reconstituted with $50 \mathrm{~mL}$ of $50 \mathrm{mM}$ potassium phosphate buffer ( $\mathrm{pH}$ 7.5) kept at $-20{ }^{\circ} \mathrm{C}$ for further protocols.

Enzyme extraction: To release the cellular contents, the strain MY1 cells were homogenized using a battery-operated motor and pestle (Pellet Pestle Motor) in $50 \mathrm{~mL}$ tubes as follows: bacterial cells $(20 \mathrm{~g}$ wet weight) were suspended in $20 \mathrm{~mL}$ of $50 \mathrm{mM}$ potassium phosphate buffer $(\mathrm{pH} 7.5)$ containing 0.1 $\mathrm{mM}$ phenylmethylsulphonylflouride (PMSF) as a protease inhibitor and $0.1 \mathrm{mM}$ dithiothreitol (DTT) as enzymes stabilizer. The cell suspension was then homogenized for $2 \mathrm{~min}$ in an ice water bath. Then, 10 $\mathrm{mL}$ of phosphate buffer was added into the homogenate and re-homogenized for $2 \mathrm{~min}$. The homogenate was further mixed using a vortex mixer (vortex IR N2400-0001, Star Lab, Italy) by pulse vortexing after the addition of $5 \mathrm{~mL}$ potassium phosphate buffer. The homogenate was then centrifuged at $10,000 \mathrm{rpm}$ for $10 \mathrm{~min}$ using a refrigerated centrifuge (ROTINA 380, Hettich, Germany) at $4{ }^{\circ} \mathrm{C}$. The supernatant was carefully decanted in a tube while the cellular debris was discarded. The supernatant was stored in an $-20{ }^{\circ} \mathrm{C}$ refrigerator for partial protein purification.

Activation of DEAE-cellulose: This activation protocol was established by the manufacturer, SigmaAldrich, United Kingdom. The dry resin ( $8 \mathrm{~g}$ ) was suspended in $50 \mathrm{~mL}$ distilled water and allowed to settle for $30-45 \mathrm{~min}$. The volume of resin was measured and regarded as the Column Volume CV (20 $\mathrm{mL}$ ) that was used for measuring the washing solutions. The suspended resin was filtered and resuspended in $40 \mathrm{~mL}$ of $0.1 \mathrm{M} \mathrm{NaOH}$ containing $0.5 \mathrm{M}$ $\mathrm{NaCl}$ for $10 \mathrm{~min}$. Then the slurry formed was poured into a Buchner funnel $(60 \mathrm{~mL})$ while applying GENTLE suction and allowing a flow of $10 \mathrm{~mL}$ buffer in $5 \mathrm{~min}$. The slurry was further washed with $40 \mathrm{~mL}$ of $0.1 \mathrm{M} \mathrm{NaOH}$ containing $0.5 \mathrm{M} \mathrm{NaCl}$ again. The washing step was repeated using $0.5 \mathrm{M} \mathrm{NaCl}$ (without $0.1 \mathrm{M} \mathrm{NaOH}$ ) and the washing cycle was further repeated using $0.1 \mathrm{M} \mathrm{HCl}$ containing $0.5 \mathrm{M} \mathrm{NaCl}$. The final washing step was done using $70 \mathrm{~mL}$ deionized water until the effluent $\mathrm{pH}$ value was 5 . The resin was suspended in $40 \mathrm{~mL}$ of $1 \mathrm{M} \mathrm{NaCl}$ and the $\mathrm{pH}$ of the slurry was adjusted to 7.5 with $\mathrm{NaOH}$ and allowed to stand for $2 \mathrm{~h}$. The resin was then filtered and $100 \mathrm{~mL}$ of distilled water was passed through the resin on the filter. Then the resin was re-suspended with $40 \mathrm{~mL}$ of $500 \mathrm{mM}$ sodium phosphate buffer $(\mathrm{pH} 7.5)$ and filtered. The resin was removed from the funnel and re-suspended with $100 \mathrm{~mL}$ of $50 \mathrm{mM}$ buffer and filtered again. This was followed by re-suspension of resin with $40 \mathrm{~mL}$ of $50 \mathrm{mM}$ sodium phosphate buffer. A small portion of the suspension was filtered and the $\mathrm{pH}$ of the filtrate was measured. The $\mathrm{pH}$ was within the range of 0.15 units of the $50 \mathrm{mM}$ buffer, making the resin to be ready for use. Later, the resin was packed into a column of $20 \times 100 \mathrm{~mm}$ capacity. Gravity flow of buffer was applied for washing resin and sample elution.

DEAE-cellulose: The supernatant containing the enzymes $(30 \mathrm{~mL})$ was applied onto the activated DEAE-cellulose column $(20 \times 100 \mathrm{~mm})$ equilibrated 
with $50 \mathrm{mM}$ potassium phosphate buffer ( $\mathrm{pH} 7.5)$. The column was washed with the buffer $(\mathrm{pH} 7.5)$, then elution was carried out with a linear gradient of 50 to $500 \mathrm{mM}$ potassium phosphate buffer, $\mathrm{pH} 7.5$ in the mixing chamber; flow rate $30 \mathrm{~mL} / \mathrm{h}$; each fraction, 5 $\mathrm{mL}$. The enzyme was eluted at a particular buffer concentration. Active fractions were concentrated by adding ammonium sulfate (70\% saturation) and then dialyzed against $5 \mathrm{mM}$ potassium phosphate buffer (pH 7.5).

Gel filtration: A $5 \mathrm{~g}$ of Sephadex G-100 was suspended in $50 \mathrm{mM}$ potassium phosphate buffer $(\mathrm{pH} 7.5)$ for 72 $\mathrm{h}$, it was degassed, and packed in a glass column (300 $\times 25 \mathrm{~mm}$ ), and equilibrated with $50 \mathrm{mM}$ potassium phosphate buffer ( $\mathrm{pH} 7.5$ ). The proteins (enzymes) solution obtained from ion-exchange (DEAEcellulose) was applied to a Sephadex column and then eluted with the same buffer at a flow rate of 0.5 $\mathrm{mL} / \mathrm{min}$.

SDS-PAGE electrophoresis: Sodium dodecyl sulfatepolyacrylamide gel electrophoresis (SDS-PAGE) was carried out using CS-550V Cleaver Scientific SDSPAGE electrophoretic system (United Kingdom) with a serial number 150603 034. A ready-made TruPAGE Precast Gels 4-12\% from Sigma-Aldrich, UK (10 cm $\times 10 \mathrm{~cm}-0.1 \mathrm{~cm} \times 12$ wells) were used for loading the Bio-Rad medium-range protein ladder, crude and partially purified protein samples as described by Laemmli, (1970). The gel was visualized by using a calibrated G-800 Densitometer (Bio-Rad).

Bradford assay: Bradford assay was performed to prepare a standard curve using bovine serum albumin and also to determine the protein concentration (Bradford, 1976). The standard curve was prepared using various concentrations of albumin mixed with 5 $\mathrm{mL}$ of Bradford reagent. The mixture was shaken and the absorbance was read using $6705 \mathrm{UV} / \mathrm{V}$ is Spectrophotometer, (JENWAY, Cole-Parmer Ltd., UK) at $595 \mathrm{~nm}$. The sample protein was also prepared by mixing $100 \mu \mathrm{L}$ of the sample and $5 \mathrm{~mL}$ of Bradford reagent and the absorbance was taken at $595 \mathrm{~nm}$.

\section{Determination of $\boldsymbol{p}, \boldsymbol{p}$ '-DDT dehalogenase activity}

Chloride ion detection assay: The activity of the partially purified dehalogenase from strain MY1 towards dechlorination of $p, p$ '-DDT was measured by its ability to release chlorine ions from the substrate. The chloride ion detection assay described by McGuinness et al. (2007) was used to quantitate the number of chloride ions released.
One unit of dehalogenase activity is the amount of enzyme that catalyzed the release of 1 micromolar of chloride ion per litre per minute $\left(\mu \mathrm{mol} \mathrm{L} \mathrm{L}^{-1} \mathrm{~min}^{-1}\right)$.

Optimum $p H$ and temperature: To determine the optimum $\mathrm{pH}$ and temperature of the $p, p^{\prime}$-DDT dehalogenase, the enzyme preparation was incubated at various $\mathrm{pH}$ values $(5.5,6.0,6.5,7.0,7.5,8.0$, and $8.5)$ and different temperatures $(20,25,30,35,40$ and $\left.45^{\circ} \mathrm{C}\right)$ under shaking $(100 \mathrm{rpm})$ for $16 \mathrm{~h}$ as described in the chloride detection assay protocol.

Effect of heavy metals on p,p'-DDT dehalogenase activity: To determine the effect of selected metal activators/inhibitors on the activity of the dehalogenase from strain MY1 on dechlorination of $p, p$ '-DDT, the assay mixtures comprised metals $\left(\mathrm{Fe}^{2+}\right.$, $\mathrm{Zn}^{2+}, \mathrm{Cu}^{2+}, \mathrm{Ag}^{2+}$ and $\mathrm{Hg}^{2+}$ ) at a final concentration of $1 \mathrm{mM}$ as described by Abdul Hamid et al. (2011). Then incubated accordingly, and the chloride ions released was determined.

Statistical analysis: The activity of $p, p$ 'DDTdehalogenase from strain MY1 was performed in triplicates and the data represent the means together with standard deviation ( \pm SD) of three independent experiments each. Analysis of variance (ANOVA) and student's t-test were used to analyze the data using OriginPro 8.5 software and MS-excel analytical tool pack. The significance was determined at a 95\% confidence limit.

\section{RESULTS AND DISCUSSION}

Purification of $p, p^{\prime}-D D T$ dehalogenase from Aeromonas sp. strain MY1: The p,p'-DDT dehalogenase from strain MY1 was isolated from cells of cultures that were grown in the presence of $p, p^{\prime}-$ DDT as an inducer, and LB broth as a nutrient source as described in the methodology section. There was no $p$, $p$ '-DDT dehalogenase activity when the cells were grown in the LB broth, indicating that the enzyme is an inducible enzyme, produced in the presence of $p, p$ 'DDT in the growth medium. The partial purification of $p, p$ '-DDT dehalogenase from strains MY1 was determined by DEAE-cellulose and Sephadex gel filtration. The purity of the enzyme was confirmed using SDS-PAGE, which also determined the approximate molecular weight of the enzyme.

Determination of molecular weight: The SDS-PAGE analysis of $p, p$ '-DDT dehalogenase from strain MY1 revealed a single band with a molecular weight of approximately $37 \mathrm{KDa}$ (Figure 1). This dehalogenase was thought to be a monomeric protein. Many researchers reported various bacterial dehalogenases with molecular weights close to that of $p, p$ '-DDT dehalogenase from strain MY1 (Keuning et al., 1985; 
Jugder et al., 2017;). Although some literature documented many bacterial monomeric dehalogenases with much high molecular weights than that of p,p'-DDT dehalogenase (Müller et al., 2004; Abdul Hamid et al., 2011).

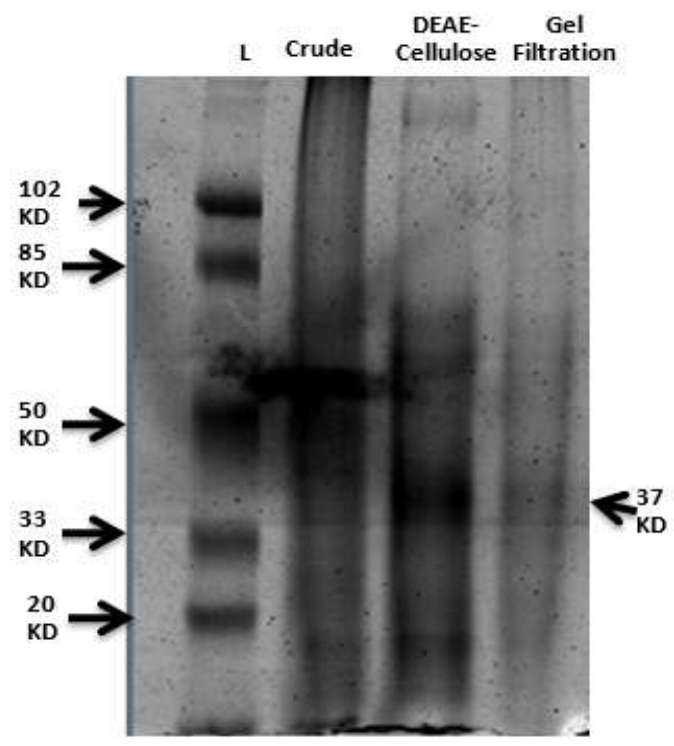

Fig 1: SDS-PAGE showing purification steps of $p, p^{\prime}$-DDT dehalogenase from Aeromonas sp. strain MY1. L represents a BioRad medium-range protein ladder.

Determination of purification fold and protein activity of the dehalogenase: The DEAE-cellulose fraction of the $p, p^{\prime}$-DDT dehalogenase from strain MY1 produced $47 \mathrm{mg}$ of the partially purified enzyme and enzyme activity of 124 (Unit) and percentage yield of $52 \%$. The Sephadex gel-purified $p, p^{\prime}$-DDT dehalogenase yielded $20 \mathrm{mg}$ of the purified enzyme with a percentage yield of $40 \%$. The specific activity of the dehalogenase towards $p$, $p$ '-DDT was found to be $4.8(\mathrm{Unit} / \mathrm{mg})$ (Table 1). From the total protein in the crude extract of $p, p$ '-DDT induced cells, the dehalogenase protein contributed to nearly $1.4 \%$ of the total protein contents.

\section{Characterization of p,p'-DDT dehalogenases purified from strain MY1}

Effect of $p H$ on the activity of $p, p$ '-DDT dehalogenases purified from strain MY1: The effect of $\mathrm{pH}$ on the activity of $p, p$ '-DDT dehalogenase was determined using the Sephadex gel-purified fraction of the enzyme. The $p, p$ '-DDT dehalogenase from strain MY1 has optimum activity at $\mathrm{pH}$ 8.0. However, the enzyme demonstrated activity within a broad $\mathrm{pH}$ range of 6.0 to 8.5 (Figure 2).

Table 1: Purification of $p, p^{\prime}$-DDT dehalogenase from Aeromonas sp. strain MY1

\begin{tabular}{lllllll}
\hline & $\begin{array}{l}\text { Volume } \\
\text { (mL) }\end{array}$ & $\begin{array}{l}\text { Protein } \\
\text { (mg) }\end{array}$ & $\begin{array}{l}\text { Activity } \\
\text { (Unit) }\end{array}$ & $\begin{array}{l}\text { Specific Activity } \\
\text { (Unit/mg) }\end{array}$ & $\begin{array}{l}\text { Purification } \\
\text { (fold) }\end{array}$ & $\begin{array}{l}\text { Yield } \\
(\%)\end{array}$ \\
\hline Crude Extract & 20 & 1430 & 237 & 0.17 & 1 & 100 \\
DEAE cellulose & 4 & 47 & 124 & 2.64 & 15.5 & 52 \\
Gel filtration & 2 & 20 & 96 & 4.8 & 28 & 40 \\
\hline
\end{tabular}

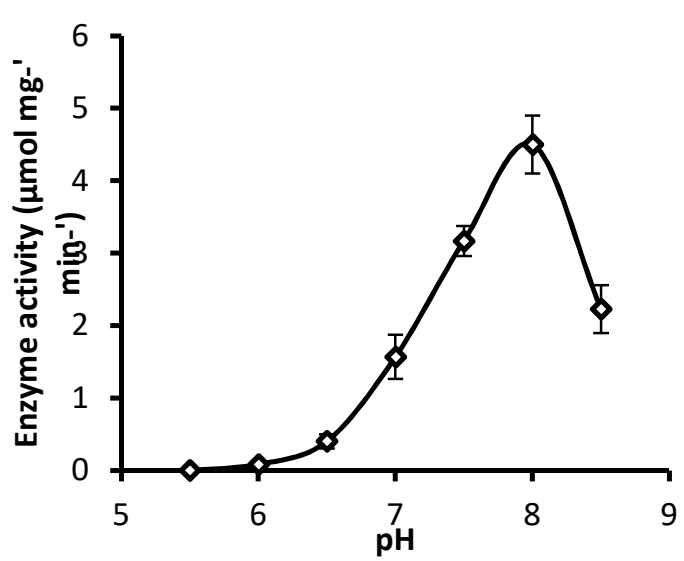

Fig 2: Effect of $\mathrm{pH}$ on the activity of $p, p^{\prime}$-DDT dehalogenase from strain MY1 towards $p, p$ '-DDT dechlorination. The experinments were conducted in triplicate.

The effect of temperature on the activity of dehalogenase from strain MY1 was determined at a range of temperatures between 20 to $50^{\circ} \mathrm{C}$. A dramatic decrease in the activity of the enzyme was observed outside the temperature range of 20 to $40^{\circ} \mathrm{C}$. However, the dehalogenase demonstrated an optimum dehalogenation activity at $35^{\circ} \mathrm{C}$ (Figure 3 ).

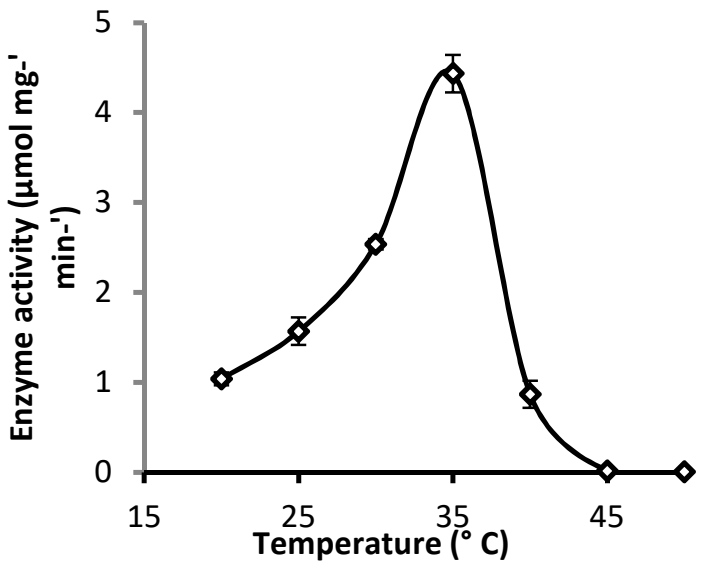

Fig 3: Effect of temperature on the activity of $p, p$ '-DDT dehalogenase from strain MY1 towards $p, p$ '-DDT dechlorination. The experinments were conducted in triplicate.

The dehalogenase demonstrated an optimum activity at a $\mathrm{pH}$ of 8.0 and a temperature of $35^{\circ} \mathrm{C}$. This is not surprising by considering the environmental 
conditions of the tropical region where strain MY1 was isolated. Alteration of $\mathrm{pH}$ or temperature, the dechlorination capacity of the enzyme is lowered. Temperature and $\mathrm{pH}$ are vital to microbial protein stability and functions since any alteration may result in the denaturation of functional proteins and consequent inactivation. It is therefore pertinent to ascertain the desired temperature and $\mathrm{pH}$ for optimum activity of the enzyme for effective application in bioremediation. Buryska et al. (2018) and Liang et al. (2019) reported some bacterial dehalogenases with a similar range of $\mathrm{pH}$ and temperature range.

Kinetic parameters of $p, p^{\prime}-D D T$ dehalogenase purified from strain MY1: The Aeromonas sp. strain MY1 was found to inducibly produced $p, p$ '-DDT dehalogenase when grown on $p, p$ '-DDT supplemented growth medium. The study of this $p, p$ '-DDT dehalogenase is vital due to the spatial location of the chlorine substituent in dictating the susceptibility of chlorinated aromatic compounds, especially the persistent $p, p$ '-DDT to degradation by microbial enzymes. Chlorine atom is known to interfere with the activity of some enzymes to degrade chlorinated aromatic compounds.

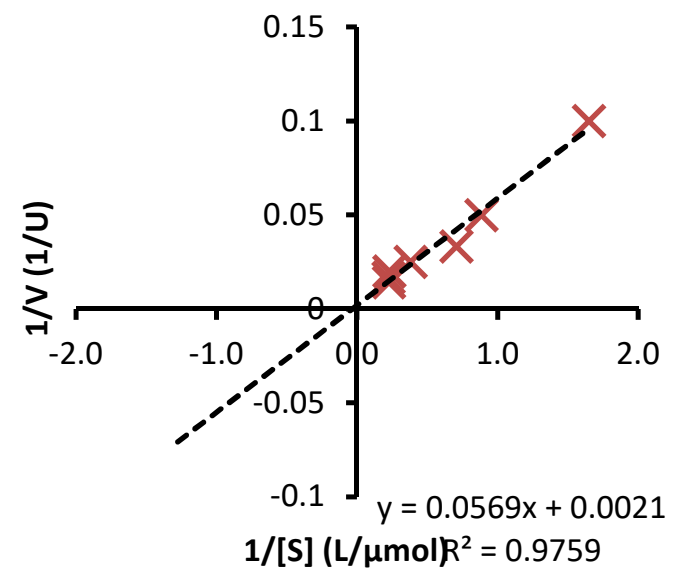

Fig 4: The Lineweaver-Burk plot of gel-purified $p, p$ '-DDT dehalogenase from strain MY1. With the $p, p$ '-DDT substrate, the enzyme followed Michaelis-Menten's kinetics

This interference was thought to be stemming from both steric and electrostatic interactions demonstrated by chlorine substituent, making the chlorinated aromatic compounds more resistant to degradation and more persistent in the environment (Copley, 1997). The success of the degradation of any chlorinated aromatic compound depends largely on the removal of chlorine substituent which paves way for further degradation via the opening of the aromatic rings and enhancing the susceptibility of the compound for complete degradation. The kinetic parameters of $p, p$ 'DDT dehalogenase from strain MY1 were determined.
The $\mathrm{Km}$ and Vmax values were derived from the computed Lineweaver-Burk plot (Figure 4). With the $p, p^{\prime}$-DDT substrate, the enzyme followed MichaelisMenten's kinetics and measurement of initial velocities with various $p, p$ '-DDT concentrations showed a Km of $27.05 \mu \mathrm{mol} \mathrm{L} \mathrm{L}^{-1}$ and $\mathrm{Vmax}$ (476.19) $\mu \mathrm{mol} \mathrm{L}{ }^{-1} \min ^{-1}$ (Table 2). Keuning et al. (1985) and Kurihara et al. (2003) reported a dehalogenase that also followed Michaelis-Menten's behaviour.

Table 2: The Km and Vmax of gel-purified $p$,p'-DDT dehalogenases from strain MY1

\begin{tabular}{|c|c|c|}
\hline Enzyme & $\begin{array}{l}\mathrm{Km} \\
(\mu \mathrm{mol} / \mathrm{L})\end{array}$ & $\begin{array}{l}\operatorname{Vmax}\left(\mu \mathrm{mol} \mathrm{L}{ }^{-1}\right. \\
\left.\min ^{-1}\right)\end{array}$ \\
\hline $\begin{array}{l}p, p p^{\prime} \text {-DDT } \\
\text { dehalogenase }\end{array}$ & 27.05 & 476.19 \\
\hline
\end{tabular}

Effect of heavy metals on the p,p'-DDT dehalogenase activity: Metal ions modulate enzyme activity by serving as either activators or inhibitors. $\mathrm{Fe}^{2+}, \mathrm{Zn}^{2+}$, $\mathrm{Cu}^{2+}, \mathrm{Ag}^{2+}$ and $\mathrm{Hg}^{2+}$ were tested for their effects on the activity of the $p, p^{\prime}$-dehalogenase from strain MY1. The dehalogenase showed loss of activity after incubation with $1 \mathrm{mM} \mathrm{Ag}{ }^{2+}$ and $\mathrm{Hg}^{2+}$, demonstrating no residual activity concerning $\mathrm{Ag}^{2+}$. Interestingly, there was no loss of activity in the presence of $1 \mathrm{mM}$ $\mathrm{Fe}^{2+}, \mathrm{Zn}^{2+}$, and $\mathrm{Cu}^{2+}$ respectively (Figure 5).

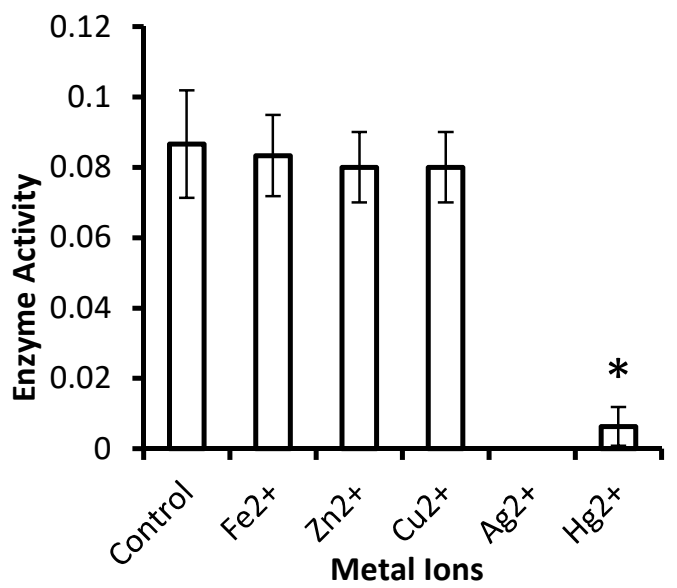

Fig 5: Effect of metal ions on the activity of $p, p$ '-DDT dehalogenase from strain MY1 towards $p, p^{\prime}$-DDT. The results are expressed as the number of chloride ions released in $\mu \mathrm{m} . \mathrm{mg}^{-1}$ of the enzyme. The results are means $\pm \mathrm{SD}$ of three independent triplicate determinations. Values with ' $*$ ' indicate a significant difference (at $\mathrm{P}<0.05$ ) when compared with their respective control.

The enzyme demonstrated no residual activity for $\mathrm{Ag}^{2+}$ and a very negligible activity for $\mathrm{Hg}^{2+} \cdot \mathrm{Ag}^{2+}$ and $\mathrm{Hg}^{2+}$ are well-known thiol reagents capable of inhibiting the catalytic activity of the thiol-containing enzyme's active sites (Keuning et al., 1985; Warner et al., 2005; Abdul Hamid et al. 2011; Agarwal et al., 2017). This suggested that the active site of $p$, $p$ '-DDT dehalogenase from strain MY1 may contain a thiol group and the probable participation of the group in 
the enzyme's catalytic strategy. Abdul Hamid et al. (2011) observed a similar scenario in 3chloroproprionate dehalogenase from Pseudomonas sp. B6P. Interestingly, there was no loss of activity in the presence of $1 \mathrm{mM} \mathrm{Fe}^{2+}, \mathrm{Zn}^{2+}$ and $\mathrm{Cu}^{2+}$ respectively. However, these metals did not produce any stimulatory effect on the dehalogenase activity.

Conclusion: Following Michaelis-Menten's behaviour, the $p, p^{\prime}$-DDT dehalogenase from Aeromonas sp. strain MY1 was unique for its capability to release chloride ions from $p, p$ '-DDT substrate. Although the enzyme has lost its dehalogenase activity in presence of metallic thiol reagents, the dehalogenase could still pave way for the effective decontamination of $p, p$ '-DDT contaminated environment, suggesting its potentials for $p, p$ '-DDT bio-cleansing applications.

\section{REFERENCES}

Abdul Hamid, THT; Hamid, AAA; Zulkifly, AH; Hamdan, S; Ariffin, SHZ; Huyop, F (2011). Purification and properties of a new dehalogenase enzyme from Pseudomonas sp. B6P grows in 3chloropropionate (3CP). Afri J Biotechnol. 10 (4): 610-614.

Abdul Kader M. (2019). Domination of pollutant residues among food products of South-East Asian Countries, Acta Sci Pharm Sci, 3(9):75-79.

Agarwal, V; Miles, ZD; Winter, JM; Eustaquio, AS; El Gamel, AA; Moore, BS (2017). Enzymatic halogenations and dehalogenation reactions: pervasive and mechanistically diverse. Chem Rev, 117(8): 5619-5674.

Anand, N (2019). Pesticide Residues in Urban and Semi-Urban Regions of West Bengal, India: Risk Assessment in Human Milk and Water. Ph.D. thesis, Indian Institute of Science Education and Research Kolkata: https://www.iiserkol.ac.in

Bradford, MM (1976). A rapid and sensitive method for the quantitation of microgram quantities of protein utilizing the principle of protein-dye binding. Anal Biochem, 72(1-2): 248-254.

Buryska, T; Babkova, P; Vavra, O; Damborsky, J; Prokop, Z (2018). A haloalkane dehalogenase from a marine microbial consortium possessing exceptionally broad substrate specificity. Appl. Environ. Microbiol., 84:e01684-17.

Bussolaro, D; Filipak, Neto, F; Glinksi, A; Roche, H; Guiloski, IC; Mela, M; Silva de Assis, HC;
Oliveira Ribeiro, CA (2012). Bioaccumulation and related effects of PCBs and organochlorinated pesticides in freshwater fish Hypostomus Commersoni. J Environ Monit, 14(8):2154-2163.

Cohn, BA; Cirillo, PM; Terry, MB (2019). DDT and breast cancer: a prospective study of induction time and susceptibility windows, $J$ Nat Cancer Inst doi: 10.1093/jnci/djy198.

Copley, SD (1997). Diverse mechanistic approaches to difficult chemical transformations: the microbial transformation of chlorinated aromatic compounds. Chem Biol. 4(3): 169-174.

Fang, H; Dong, B; Yan, H; Tang, F; Yu, Y (2010). Characterization of a bacterial strain capable of degrading DDT congeners and its use in bioremediation of contaminated soil, J Haz Mat, 184: 281-289.

Foght, J; April, T; Biggar, K; Aislable, K (2001). Bioremediation of DDT-contaminated soils: A Review, Biorem J. 5(3): 225-245

Hadara, T; Takeda, M; Kojima, S; Tomiyama, N (2016). Toxicity and carcinogenicity of dichlorodiphenyltrichloroethane (DDT). Toxicol Res, 32(1):21-33.

Jugder, BE, Ertan, H., Bohl, S., Lee, M., Marquis, C.P., and Manefield, M. (2016) Organohalide respiring bacteria and reductive dehalogenases: key tools in organohalides bioremediation. Front Microbiol, 7: 249.

Jugder, B; Bohl, S; Lebhar, H; Healey, RD; Manefield, M; Marquis, CP; Lee, M (2017). A bacterial chloroform reductive dehalogenase: purification and biochemical characterization. Microbial Biotechnol, 10: 1640-1648.

Keuning, S; Janssen, DB; Witholt, B (1985). Purification and characterization of a hydrolytic haloalkane dehalogenase from Xanthobacter autotrophicus GJ10. J Bacteriol, 163(2): 635-639.

Kurihara, T; Yamauchi, T; Ichiyama, S; Takahata, H; Esaki, N (2003). Purification, characterization, and gene cloning of a novel fluoroacetate dehalogenase from Burkholderia sp. FA1. J. Mole Cat B: Enzymatic, 23: 347-355.

Laemmli, UK (1970). Cleavage of structural proteins during the assembly of the head of bacteriophage T4. Nat, 227(5259):680-685. 
Liang, Z; Li, G; Xiong, J; Mai, B; An, T (2019) Purification, molecular characterization and metabolic mechanism of anaerobic tetrabromobisphenol A dehalogenase, a key enzyme ofhalorespiration in Ochrobactrum sp. T Chemosphere, 237: 1244613

Magnuson, J.K; Romine, MF; Burris, DR; Kingsley, MT (2000) Trichloroethene reductive dehalogenase from Dehalococcoides ethenogenes: the sequence of tce A and substrate range characterization. Appl Environ Microbiol, 66: 5141-5147.

McGuinness, M; Marzurkiewicz, V; Brennan, E; Dowling, DN (2007). Dehalogenation of pesticide by a specific bacterial glutathione S-transferase, Bphk LB400: Potential for bioremediation. Eng Life Sci, 7(6):611-615

Mendes, RA; Lima, MO; de Deus, RJA; Medeiros, AC; Faial, KCF; Jesus, IM; Faial, KRF; Santos, LS (2019). Assessment of DDT and mercury levels in fish and sediments in the Iriri River, Brazil: distribution and ecological risk, J Environ Sci He, B. 9:1-10.

Mnif, W; Hassine, AH; Bouaziz, A; Bargeti, A; Thomas, O; Roig, B (2011). Effect of Endocrine disruptor pesticides: A review. Int J Res Pub He, 8:2236-2303.

Motosugi, K., Esaki, K. T., and Soda, K. (1982). Purification and properties of a new enzyme, DL2-Haloacid dehalogenase, from Pseudomonas sp. J Bacteriol, 150(2):522-527.

Müller, JA; Rosner, BM; Von Abendroth, G; Meshulam-Simon, G; McCarty, PL; Spormann, AM (2004). Molecular identification of the catabolic vinyl chloride reductase from Dehalococcoides sp. strain VS and its environmental distribution. Appl Environ Microbiol, 70: 4880-4888

Murtala, Y; Nwanguma BC; Ezeanyika LUS (2020). Isolation and characterization of a novel p,p'DDT degrading bacterium: Aeromonas sp. strain MY1. Asian J Biotechnol Bioresour Technol, 6(4):12-22.

Mwangi, K; Boga, HI; Muigai, AW; Kiiyukia, C; Tsanuo, MK (2010). Degradation of dichlorodiphenyltrichloroethane (DDT) by bacterial isolates from cultivated and uncultivated soil. Afri J Microbiol Res, 4(3): 185-196
Ogbeide, O; Tongo, I; Ezemonye, L (2015). Risk assessment of agricultural pesticides in water, sediment, and fish from Owan River, Edo State, Nigeria. Environ Monit Assess, 187:654-666.

Sheldon M; Pinion JC; Klyza J; Zimeri, A (2019). Pesticide contamination in Central Kentucky urban honey: A Pilot Study. $J$ Environ Health, 82(1): 8-13.

Sudharshan, S; Naidu, R; Mallavarapu, M; Bolan, N (2012). DDT remediation in contaminated soils: a review of recent studies. Biodeg, 23(6):851863.

Thompson, LA; Ikenaka, Y; Darwish, WS; Nakayama, SM; Mizukawa, H (2019). Effects of the organochlorine $p, p$ '-DDT on MCF-7 cells: Investigating metabolic and immune-modulatory transcriptomic changes Environ Toxicol Pharmacol, 72:103249.

Truong, KM; Cherednichenko, G; Pessah, IN (2019). Interactions of Dichlorodiphenyltrichloroethane (DDT) and Dichlorodiphenyldichloroethylene (DDE) With Skeletal Muscle Ryanodine Receptor Type 1. Toxicol Sci, 170(2):509-524

van den Berg, H; Manuweera, G; Konradsen, F (2017). Global trends in the production and use of DDT for control of malaria and other vector-borne diseases. Malaria J, 16:401.

Warner, JR; Lawson, SL; Copley, SD (2005). A mechanistic investigation of the thiol-disulfide exchange step in the reductive dehalogenation catalyzed by tetrachloro-hydroquinone dehalogenase. Biochem, 44(30): 10360-10368.

Wu, RX; Li, YP; Tu, SX; Ding, YZ; Wang, RG; Rensing, C; Feng, RW (2019). Elevated atmospheric $\mathrm{CO}_{2}$ might increase the health risk of long-term ingestion of leafy vegetables cultivated in residual DDT polluted soil. Chemosphere, 227:289-298. 